\title{
Sternal foramen as extracardiac findings in cardiac computed tomography
}

\section{Otwór mostka jako zmiana pozasercowa w badaniach tomografii komputerowej serca}

\author{
Michał Spałek ${ }^{1,2}$, Małgorzata Zychowska, Przemysław Wolak ${ }^{3,4}$, Jakub Spałek$^{5}$, Tadeusz Kuder ${ }^{1}$ \\ ${ }^{1}$ Department of Anatomy, Institute of Medical Sciences, Faculty of Medicine and Health Sciences, \\ Jan Kochanowski University, Kielce, Poland \\ Head of the Department: Prof. Tadeusz Kuder PhD \\ 2Department of Diagnostic Imaging, Świętokrzyskie Oncology Centre, Kielce, Poland \\ Head of the Department: Tomasz Drożdż MD \\ ${ }^{3}$ Department of Paediatrics, Paediatric and Social Nursing, Institute of Nursing and Midwifery, Faculty of Medicine and Health Science, \\ Jan Kochanowski University Kielce, Poland \\ Head of the Department: Mieczysław Szalecki MD, PhD, Prof. JKU \\ ${ }^{4}$ Department of Paediatric Surgery, Urology and Traumatology, Voivodeship Specialist Hospital, Kielce, Poland \\ Head of the Department: Przemystaw Wolak MD, PhD \\ ${ }^{5}$ Department of Physiology, Institute of Medical Sciences, Faculty of Medicine and Health Sciences, Jan Kochanowski University, \\ Kielce, Poland \\ Head of the Department: Prof. Robert Bucki MD, PhD
}

Medical Studies/Studia Medyczne 2016; 32 (4): 274-278

DOI: $10.5114 / \mathrm{ms} .2016 .64700$

Key words: sternal foramen, cardiac computed tomography, acupuncture, trepanobiopsy.

Słowa kluczowe: otwór mostkowy, tomografia komputerowa serca, akupunktura, trepanobiopsja.

\begin{abstract}
Introduction: According to the recommendations made by associations engaged in the diagnostics of cardiovascular diseases, a physician who interprets an imaging scan of this organ should consider in the report also changes in other structures covered by the examination. One of the structures observed in cardiac computed tomography (CCT) is the sternum.

Aim of the research: The authors of the presented article wish to pay attention to the developmental defect of this bone - the sternal foramen, which may sometimes be of importance in some medical and paramedical procedures. Knowledge concerning the presence of such a foramen in the patient subjected to the procedure of bone marrow trepanobiopsy or acupuncture may protect against dangerous complications resulting from the puncture of the heart structures or the large vessels of the mediastinum.

Material and methods: Into the study group were qualified 134 patients (78 females and 56 males), aged from 29-84 years, in whom CCT was performed.

Results: Sternal foramen was found in eight males and one female, the majority in the lower part of the body of the sternum. The results obtained did not differ from reports available in literature.

Conclusions: Sternal foramen is a frequently observed developmental defect, which should always be included in the description of the CCT scan and other imaging tests covering the sternum. Preliminary results of the study suggest a significant correlation between the frequency of its occurrence according to gender; however, the confirmation or exclusion of such a relationship requires further analysis on a larger group of patients.
\end{abstract}

\section{Streszczenie}

Wprowadzenie: Zgodnie z wytycznymi towarzystw zajmujących się diagnostyka chorób serca lekarz opisujacy badanie obrazowe tego narządu powinien uwzględnić w swoim raporcie również zmiany w innych strukturach objętych badaniem. Jedną ze struktur widocznych w badaniu tomografii komputerowej serca (CCT) jest mostek.

Cel pracy: Autorzy niniejszego artykułu chcą zwrócić uwagę na defekt rozwojowy tej kości, jakim jest otwór mostkowy, który może mieć czasem znaczenie w niektórych zabiegach medycznych i paramedycznych. Wiedza o obecności takiego otworu u pacjenta poddawanego na przykład zabiegowi trepanobiopsji szpiku lub akupunktury może uchronić przed groźnymi powikłaniami wynikającymi z nakłucia struktur serca lub dużych naczyń śródpiersia.

Materiał i metody: Do badanej grupy włączono 134 chorych (78 kobiet i 56 mężczyzn) w wieku od 29 do 84 lat, u których wykonano CCT od stycznia do września 2016 roku.

Wyniki: U 8 mężczyzn i 1 kobiety znaleziono otwory mostkowe, większość w dolnej części trzonu mostka. Uzyskane wyniki nie odbiegają od doniesień $\mathrm{w}$ dostępnym piśmiennictwie. 
Wnioski: Otwór mostkowy jest częstym defektem rozwojowym, który powinien być zawsze odnotowany w opisie badania CCT lub innych badań obrazowych obejmujących mostek. Wstępne wyniki sugerują istotną korelację częstości jego występowania z płcią, jednak potwierdzenie lub wykluczenie takiego związku wymaga dalszej analizy w odpowiednio większej grupie osób.

\section{Introduction}

According to the recommendations made by associations engaged in the diagnostics of cardiovascular diseases - the Society of Cardiovascular Computed Tomography (SCCT), the American College of Radiology (ACR), the American Heart Association (AHA), the American Society of Echocardiography (ASE), the American Society of Nuclear Cardiology (ASNC), the North American Society for Cardiovascular Imaging (NASCI), the Society for Cardiovascular Angiography and Interventions (SCAI), the Society for Cardiovascular Magnetic Resonance (SCMR), and the American College of Cardiology Foundation Appropriate Use Criteria Task Force (ACCF) [1, 2] - a physician who interprets a heart scan should consider in the report also the changes in other organs and structures covered by the examination, including lungs, oesophagus, pulmonary vessels, aorta, thoracic wall, liver, spleen, large intestine, adrenal glands, and lymph nodes. One of the structures visible in the cardiac computed tomography (CCT) is the sternum.

\section{Aim of the research}

The authors of the presented article wish to draw attention to the developmental defect of this bone - the sternal foramen, which may sometimes be of importance in some medical and paramedical procedures. Knowledge concerning the presence of such a foramen in the patient subjected to the procedure of bone marrow trepanobiopsy or acupuncture may protect against dangerous complications resulting from the puncture of the heart structures or the large vessels of the mediastinum.

\section{Material and methods}

\section{Patient population}

Cardiac computed tomography scans were-performed in 151 patients in the Świętokrzyskie Oncology Centre during the period from January - September 2016. Into the analyzed group were enrolled 134 patients ( 78 females and 56 males), aged 29-84 years (mean age: 58.552 years, median age: 59 years); the mean age of females did not significantly differ from that of males $(p=0.9863)$. From the study group were excluded 17 patients who had undergone sternotomy. None of the examined patients had tumours or sternal infiltration changes, nor had they undergone any injury of the sternum. The patients were referred to the CCT scan for various reasons, including the assessment of: coronary arteries, left atrium of the heart and pulmonary venous drainage, and aortic valve.

\section{Cardiac computed tomography protocol}

The study was conducted using a 64-slice scanner SOMATOM Definition AS (Siemens); scanning parameters were as follows: $120 \mathrm{kV}, 40 \mathrm{mAs}$ (Calcium scoring) and $160 \mathrm{mAs}$ (angio), $128 \times 0.6 \mathrm{~mm}$ collimation, pitch $0.18,0.3$ second gantry rotation, $3 \mathrm{~mm}$ and $0.6 \mathrm{~mm}$ reconstruction image thickness, and 200 and 400 field of view (FOV).

The scan was performed after the patient had taken a deep inspiration and held it. The scope of the examination started just below the bifurcation of the trachea, which, according to the type of structure and respiratory mobility of the chest, in the majority of patients was equivalent to the level between the second and third costal notch of the sternum, and ended approximately $10 \mathrm{~mm}$ below the apex of the heart, which, in all the patients, was equivalent to the level below the end of the xiphoid process. The upper limit of the scan, lowermost with respect to the sternum, was the plane located between the third and fourth costal notch.

\section{Image analysis}

The obtained data were subjected to post-processing using the diagnostic station Leonardo with the syngo MultiModality Workplace (syngoMMWP) software, version VE61A, VH21B (Siemens) obtaining multiplanar reconstructions - MPRs in various cross-sections allowing the best visualisation of the analysed structure. Also, maximum intensity projection (MIP) reconstructions and volume rendering technique (VRT) were used to obtain three-dimensional images. Analysis of bone structures was performed by means of images with 1500 window width and 400 window level.

\section{Statistical analysis}

For the continuous characteristics (age, dimension of the long axis of the sternum, dimension of the transverse axis of the sternum, distance from the lower edge of the body of the sternum) basic statistics were determined (mean, standard deviation, median, quartiles and maximum and minimum). For the characteristics of the category type (gender, presence of the sternal foramen, location of the foramen) frequencies and percentage values were determined. $T$ test was applied to compare the patient's age according to gender, and $\chi^{2}$ test to investigate the correlations between the occurrence of non-compaction of the sternum according to gender. Analysis was performed using MedCalc Statistical Software version 16.8.4 
Table 1. Gender and age of patients with sternal foramen. Dimensions, localisation, and distance of the foramen from the lower edge of the body of the sternum

\begin{tabular}{|c|c|c|c|c|c|c|}
\hline $\begin{array}{l}\text { Patient } \\
\text { number }\end{array}$ & Gender & $\begin{array}{c}\text { Age } \\
\text { [years] }\end{array}$ & $\stackrel{\mathrm{L}}{[\mathrm{mm}]}$ & $\begin{array}{c}\mathrm{T} \\
{[\mathrm{mm}]}\end{array}$ & Localisation & $\begin{array}{l}\text { Distance } \\
{[\mathrm{mm}]}\end{array}$ \\
\hline 1 & M & 71 & 5.8 & 3.5 & $5^{\text {th }}$ costal notch & 27 \\
\hline 2 & M & 65 & 2.3 & 2.4 & Between $5^{\text {th }}$ and $6^{\text {th }}$ costal notch & 15 \\
\hline 3 & M & 52 & 7.2 & 5.8 & $6^{\text {th }}$ costal notch & 15 \\
\hline 4 & M & 29 & 11.0 & 10.6 & $5^{\text {th }}$ costal notch & 16 \\
\hline 5 & $\mathrm{~F}$ & 53 & 5.0 & 6.8 & $5^{\text {th }}$ costal notch & 28 \\
\hline 6 & M & 59 & 1.9 & 2.9 & $5^{\text {th }}$ costal notch & 25 \\
\hline 7 & M & 60 & 3.7 & 3.1 & Between $5^{\text {th }}$ and $6^{\text {th }}$ costal notch & 22 \\
\hline 8 & M & 60 & 5.3 & 6.9 & $5^{\text {th }}$ costal notch & 23 \\
\hline 9 & M & 71 & 4.0 & 6.0 & $4^{\text {th }}$ costal notch & 50 \\
\hline
\end{tabular}

$L$-dimension of foramen along the long axis of the sternum, $T$ - dimension of foramen along the transverse axis of the sternum, Distance - distance of foramen from the lower edge of the body of the sternum.

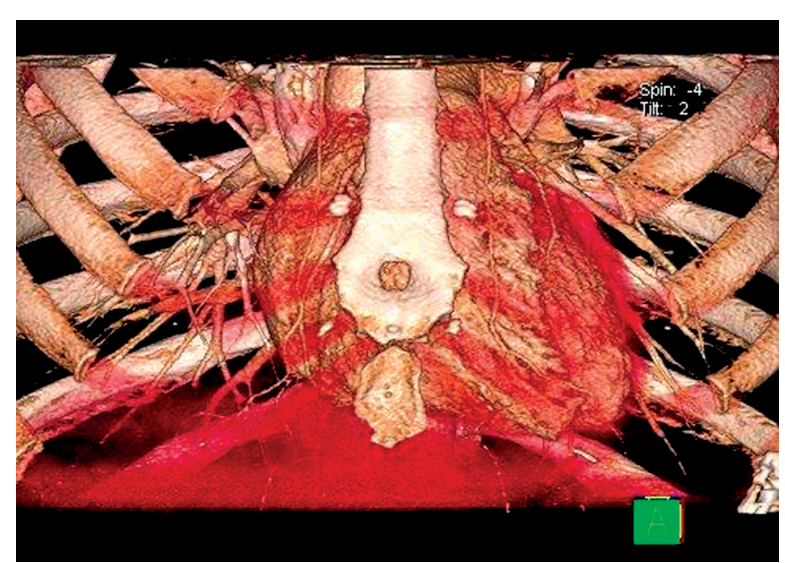

Figure 1. The largest visualised sternal foramen, cardiac computed tomography examination, volume rendering technique

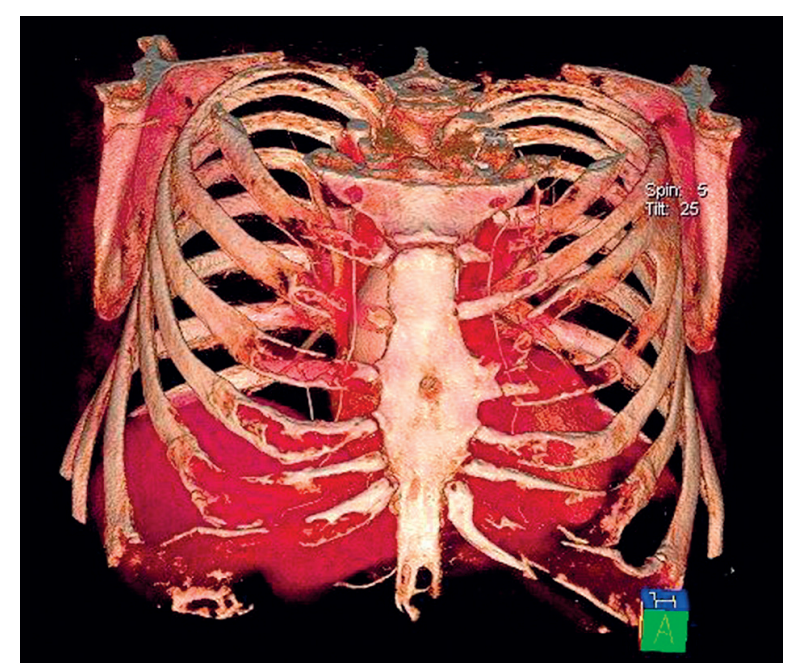

Figure 2. The sternal foramen located on the level of the fourth costal notch and the fourth left bifid rib, cardiac computed tomography examination, volume rendering technique
(MedCalc Software bvba, Ostend, Belgium; https:// www.medcalc.org; 2016).

\section{Results}

The obtained scans visualised the sternal foramen in $9(6.7 \%)$ from among 134 patients (Table 1). This foramen was significantly more frequently observed in males than in females ( $p=0.0031)$; as many as 8 of 56 males $(14.3 \%)$ had a sternal foramen, while only one women from among 78 (1.3\%).

The largest visualised foramen had the dimension of $11.0 \mathrm{~mm}$ along the long axis of the sternum, and $10.6 \mathrm{~mm}$ along the transverse axis (Figure 1). The dimensions of the remaining foramens did not exceed $7.2 \mathrm{~mm}$. The smallest dimension of the foramens found along the long axis was $1.9 \mathrm{~mm}$, and along the transverse axis $-2.4 \mathrm{~mm}$. Slightly more than a half of the foramens (55.6\%) had a larger dimension along the transverse than along the long axis of the sternum.

The most frequent location of the sternal foramen was at the level of the fifth costal notch (44.4\%), i.e. the site of connection of the third and fourth sternebrae, followed by the level of the sixth costal notch $(22.2 \%)$, and the level between the fifth and sixth costal notches (22.2\%). Both the level of the sixth costal notch and the level between the fifth and sixth costal notches are located within the fourth sternebrae. In only 1 patient the foramen was located above the junction between the third and fourth sternebrae - on the level of the fourth costal notch - in this male there also occurred a developmental anomaly of the fourth left rib in the form of a bifid rib (Figure 2).

In the person with the sternal foramen located on the level of the sixth costal notch there also cooccurred an anatomical variation consisting of direct connection with the sternum of both eighth vertebrae. In one of the patients, in whom the foramen was 
located on the fifth sternebra, there was a direct connection with the sternum of the eighth right vertebra.

The distance between the lower edge of the foramens located within the fourth sternebra, and on the level of connection of the third and fourth sternebrae and the lower edge of the body of the sternum, remained within the range of $15-28 \mathrm{~mm}$.

The distance between the lower edge of the uppermost located foramen in the examined group of patients and the lower edge of the sternum was $50 \mathrm{~mm}$.

\section{Discussion}

The CCT scan is not dedicated to the assessment of the sternum or other adjacent structures and organs. However, according to the guidelines, all the abnormalities observed, apart from the heart, should also be included in the CCT examination report.

According to the authors, one such abnormality is the sternal foramen because its presence may create the risk of dangerous complications, including cardiac tamponade during bone marrow aspiration of the sternum or some acupuncture procedures [3-7].

The sternal foramen is a relatively frequent developmental defect of the sternum, which occurs with different frequency in various populations. In the literature various data exists concerning this problem - from $4.3 \%$ in the report by Stark [8], through 4.5\% - Yekeler et al. [9], 5.1\% Aktan and Savas [10], $6.6 \%$ - Moore et al. [11], and 6.7\% - Cooper et al. [12], to $16.6 \%$ in autopsy examinations by Babiński et al. [13]; although in the same researcher in the report that occurred 3 years later concerning the analysis of multi-detector computed tomography - MDCT reported the frequency of occurrence of this defect in only $10.5 \%$ of patients [14]. El-Busaid et al. from Nairobi observed sternal foramens in $13.8 \%$ of persons, and suggested the dependence of the occurrence of this anatomical variation in the analysed population [15]. Paraskevas et al. from Greece found sternal foramens in as many as $18.3 \%$ of persons from the analysed group; however, the majority of them were located in the xiphoid process, and only $5 \%$ in the body of the sternum [16].

Despite the fact that in the presented study the whole of the sternum was not covered by the CCT scan, the frequency of occurrence of the sternal foramen in the examined group of patients was similar to reports by other researchers. This results from the fact that the sternal foramen most frequently occurs in the lower part of the body of the sternum, and this part was covered by the scan in all patients. The location of the sternal foramen is related with its ontogenesis and the number of the ossification points, which is larger just in the lower part of the body of the sternum, because sternal foramens are the result of disorders in the connection of particular osseous parts of the body of the sternum.
During its development the sternum undergoes three stages: membranous, cartilaginous, and osseous. After the adhesion of two bands of mesodermal cells at week 9 of foetal life the sternum is formed in a membranous form [17]. The sternum has several ossification points - one in the manubrium, which develops between months 3 and 6 of foetal life. Subsequently there develop ossification points in the body of the sternum, the number of which varies - usually from five to seven, but sometimes there may be more. Appropriate ossification points in the body of the sternum initially adhere by synchondrosis, and subsequently by synostosis creating four segments (sternebrae) in humans. Finally, all the segments of the body of the sternum are connected with synostosis in the third decade of life $[18,19]$.

The majority of reports do not consider the relationship between the presence of the sternal foramen and gender; however, in studies where attention was paid to such a relationship, foramens always more frequently occurred in males than in females [10, 13, 15], but the difference was not as big as in the presented study.

The differences may easily be found between the occurrence of the sternal foramen and other pathologies concerning bones, such as post-injury or cancerous changes, provided that such a developmental defect be kept in mind and that one has experience in the assessment of changes in bones.

Observation and interpretation of non-cardiac changes in the CCT scan requires knowledge and experience concerning various pathologies and developmental variations occurring in various human organs. Radiologists are specialists who, in their daily practice, deal with imaging diagnostics of various pathologies in all organs and in persons of various ages. On the other hand, the description of a CCT scan requires comprehensive knowledge in the area of diseases, defects, and developmental anomalies of the heart and vessels, and combining them with the clinical context concerning an individual patient. In turn, such knowledge is usually possessed by cardiologists and cardiac surgeons. In the authors' opinion, this fact speaks in favour of the necessity for cooperation among a radiologist, cardiologist, and often a cardiac surgeon, while interpreting the CCT scan. Considering the limitations of this report, which does not cover the whole sternum by analysis, the researchers plan to perform a retrospective analysis in the context of the sternal foramen and CT of the chest, in which the entire sternum is visualised.

\section{Conclusions}

Sternal foramen is a frequent developmental defect, which should always be included in the CCT scan report or other imaging examinations concerning the sternum. Preliminary results suggest a significant correlation between the frequency of its occurrence and 
gender; however, the confirmation or exclusion of such a relationship requires further analysis in a larger group of patients.

\section{Conflict of interest}

The authors declare no conflict of interest.

\section{References}

1. Taylor AJ, Cerqueira M, Hodgson J McB, Mark D, Min J, O'Gara P, Rubin GD; ACCF/SCCT/ACR/AHA/ASiE/ASNC/ NASCI/SCAI/SCMR 2010 Appropriate Use Criteria for Cardiac Computed Tomography. Circulation 2010; 122 : e525-55.

2. Leipsic J, Abbara S, Achenbach S, Cury R, Earls JP, Mancini GJ, Nieman K, Pontone G, Raff GL. SCCT guidelines for the interpretation and reporting of coronary CT angiography: a report of the Society of Cardiovascular Computed Tomography Guidelines Committee. J Cardiovasc Comput Tomogr 2014; 8: 342-58.

3. National Certification Commission for Acupuncture and Oriental Medicine Examination Study Guide for the Diplomate of Acupuncture Certification, 2015, https://idph. iowa.gov/Portals/1/userfiles/26/PTOT/DryNeedlingPublicCommentWeek6-5.pdf [Available at: 11.11.2016].

4. Schratter M, Bijak M, Nissel H, Gruber I, Schratter-Sehn AU. The foramen sternale: a minor anomaly - great relevance. Rofo 1997; 166: 69-71.

5. Wolochow MS. Fatal cardiac tamponade through congenital sternal foramen. Lancet 1995; 346: 442.

6. Bhootra BL. Fatality following a sternal bone marrow aspiration procedure: a case report. Med Sci Law 2004; 44: 170-2.

7. Halvorsen TB, Anda SS, Naess AB, Levang OW. Fatal cardiac tamponade after acupuncture through congenital sternal foramen. Lancet 1995; 345: 1175.

8. Stark P. Midline sternal foramen: CT demonstration. J Comput Assist Tomogr 1985; 9: 489-90.

9. Yekeler E, Tunaci M, Tunaci A, Dursun M, Acunas G. Frequency of sternal variations and anomalies evaluated by MDCT. AJR Am J Roentgenol 2006; 186: 956-60.

10. Aktan ZA, Savas R. Anatomic and HRCT demonstration of midline sternal foramina. Turk J Med Sci 1998; 28: 511-4.

11. Moore MK, Stewart JH, McCormick WF. Anomalies of the human chest plate area: radiographic findings in a large autopsy population. Am J Forensic Med Pathol 1988; 9: 348-54.

12. Cooper PD, Stewart JH, McCormick WF. Development and morphology of the sternal foramen. Am J Forensic Med Pathol 1988; 9: 342-7.

13. Babiński MA, Rafael FA, Steil AD, Sousa-Rodrigues CF, Sgrott EA, Cisne de Paula R, Fernandes RMP. High prevalence of sternal foramen: quantitative, anatomical analysis and its clinical implications in acupuncture practice. Int J Morphol 2012; 30: 1042-9.

14. Babinski MA, de Lemos L, Babinski MS, Gonçalves MV, De Paula RC, Fernandes RM. Frequency of sternal foramen evaluated by MDCT: a minor variation of great relevance. Surg Radiol Anat 2015; 37: 287-91.

15. El-Busaid H, Kaisha W, Hassanali J, Hassan S, Ogeng'o J, Mandela P. Sternal foramina and variant xiphoid morphology in a Kenyan population. Folia Morphol 2012; 71: 19-22.
16. Paraskevas G, Tzika M, Anastasopoulos N, Kitsoulis P, Sofidis G, Natsis K. Sternal foramina: incidence in Greek population, anatomy and clinical considerations. Surg Radiol Anat 2015; 37: 845-51.

17. Bartel H. Embriologia. Wydawnictwo Lekarskie PZWL, Warsaw 2012; 595-618.

18. Reicher M, Łasiński W. Rozwój żeber i mostka. In: Anatomia człowieka. Vol. I. Łasiński W (ed.). Wydawnictwo Lekarskie PZWL, Warsaw 1990; 281-2.

19. Keith A. Human Embryology and Morhology. Chapter XIX. The Body Wall, Ribs and Sternum. London: Edward Arnold, 1902; https://embryology.med.unsw.edu.au/embryology/index.php/Book_-_Human_Embryology_and_ Morphology_19 [Available at: 11.11.2016].

\section{Address for correspondence:}

Michał Spałek MD

Department of Anatomy

Institute of Medical Sciences

Faculty of Medicine and Health Sciences

Jan Kochanowski University

ul. IX Wieków Kielc 19, 25-317 Kielce, Poland

Phone: +48667330266

E-mail: michal_spa@op.pl 